\title{
ATYPICAL PNEUMONIA CAUSED BY PSITTACOSIS-LIKE VIRUSES ${ }^{1}$
}

\author{
By GORDON MEIKLEJOHN, M. DORTHY BECK, AND MONROE D. EATON \\ (From the Research Laboratory of the California State Department of Public Health, and the Department \\ of Medicine, University of California Medical School, Berkeley)
}

(Received for publication July 27, 1943)

Previous reports ( 1 to 7 ) have indicated that some of the more severe forms of atypical pneumonia may be caused by any one of a group of viruses related to psittacosis and meningopneumonitis. In several instances $(1$ to 5,14$)$, virus has been isolated from the patient. More often, however, the diagnosis has been made on the basis of the complement-fixation test which distinguishes this group of infections from other primary atypical pneumonias, but fails to differentiate between the individual viruses within the group.

This paper will present data on 10 cases of atypical pneumonia due to psittacosis-like viruses in which the etiology was determined by isolation of the virus and by serological tests, and 2 related cases which apparently were sources of infection. The strains of virus isolated fall into 2 types, one of which probably originated in pigeons and is designated pigeon ornithosis virus $(2,8,10)$, the other being of unknown origin, but probably identical with the strains isolated in 1940 (1) and designated S-F. A laboratory infection due to the meningopneumonitis virus (9) is also described.

\section{CLINICAL AND EPIDEMIOLOGICAL FINDINGS}

Cases due to pigeon ornithosis virus. Four naturally occurring infections with pigeon ornithosis virus were studied. All of these gave a history of contact with pigeons, though in one case this contact was very transient. All 4 cases were severe, presenting the picture of systemic infection with broncopneumonia of variable extent, and 2 terminated fatally. One death was peculiar in that it occurred after the infection had apparently subsided and presumably was due to the age and cardiovascular status of the patient. The other death occurred in a patient

\footnotetext{
1 The studies and observations on which this paper is based were supported by the International Health Division of The Rockefeller Foundation.
}

with fulminating infection and rapidly extending bronchopneumonia. The clinical, epidemiological, and laboratory data from these cases are summarized in the first part of Table I. The virus of pigeon ornithosis was isolated in our laboratory from the sputums of all 4 patients, and in 2 cases, a similar virus was isolated by Dr. K. F. Meyer from the pigeons in the flocks presumably responsible for infection of the patients.

Case 1 (Figure 1). B. S., male, 63, became ill on May 7,1942 , complaining of sore throat, cough, headache, chills, anorexia, and diarrhea. On May 11, he was admitted to Mt. Zion Hospital. Temperature was $106^{\circ} \mathrm{F}$., pulse 120 , irregular, respirations 24, blood pressure 132/82. Physical examination showed an elderly male of poor nutrition who was irritable and uncooperative. The pharynx was beefy red. Scattered râles were heard at the right base. The spleen was felt at the costal margin.

Laboratory findings: White blood count was 6,200 . Urine contained albumin ( $(+)$. Chest $x$-ray showed an area of uniform greyness in the L.U.L. which was interpreted as "virus pneumonia." E.C.G. showed auricular flutter and fibrillation. Routine bacteriological and serological tests were negative. White blood count fell to

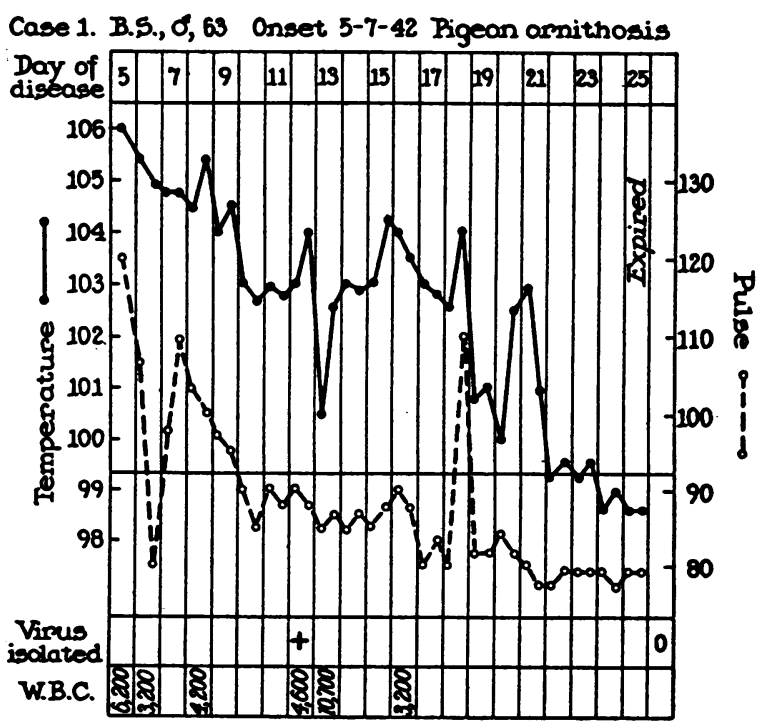

Fig. 1. Case Due to Pigeon Ornithosis Virus 
TABLE I

Summary of cases

\begin{tabular}{|c|c|c|c|c|c|c|c|c|c|c|c|}
\hline \multirow{2}{*}{$\begin{array}{l}\text { Case } \\
\text { num- } \\
\text { ber }\end{array}$} & \multirow{2}{*}{ Name } & \multirow{2}{*}{ Age } & \multirow{2}{*}{ Sex } & \multirow{2}{*}{$\begin{array}{l}\text { Dura- } \\
\text { tion of } \\
\text { fever }\end{array}$} & \multirow{2}{*}{$\begin{array}{c}\text { Height } \\
\text { of } \\
\text { fever }\end{array}$} & \multirow{2}{*}{ White blood cells } & \multicolumn{2}{|c|}{$\begin{array}{l}\text { Virus } \\
\text { isolated }\end{array}$} & \multicolumn{2}{|c|}{$\begin{array}{l}\text { Complement } \\
\text { fixation }\end{array}$} & \multirow{2}{*}{ Epidemiology } \\
\hline & & & & & & & $\begin{array}{l}\text { Day of } \\
\text { illness }\end{array}$ & Type & $\left|\begin{array}{c}\text { Day of } \\
\text { illness }\end{array}\right|$ & Titer & \\
\hline 1 & B. S. & $\begin{array}{c}\text { years } \\
63\end{array}$ & $\mathbf{M}$ & $\begin{array}{c}\text { days } \\
25+\end{array}$ & $\begin{array}{l}\circ F \\
106\end{array}$ & 3,200 to 6,200 & 12 & P.O. & 25 & $>1: 32$ & $\begin{array}{l}\text { Pigeon contact. Similar vi } \\
\text { rus recovered from other } \\
\text { birds in flock }\end{array}$ \\
\hline 2 & M. P. & 38 & $\mathbf{M}$ & 35 & 105.2 & 5,600 & 24 & P.O. & $\begin{array}{l}31 \\
46\end{array}$ & $\begin{array}{l}>1: 256 \\
>1: 256\end{array}$ & $\begin{array}{l}\text { Transient pigeon, parrot, } \\
\text { and chicken contact. Bird } \\
\text { sera negative by C-F test }\end{array}$ \\
\hline 3 & A. $\mathrm{B}$. & 36 & F & 20 & 104.3 & 8,450 & 9 & P.O. & 9 & $1: 32$ & Fed flock of wild pigeons \\
\hline 4 & R. C. & 48 & M & $13+$ & 105.6 & 7,200 to 10,000 & 8 & P.O. & 9 & $1: 4+$ & $\begin{array}{l}\text { Pigeon contact. Cleaned } \\
\text { loft } 2 \text { weeks before onset of } \\
\text { illness. Similar virus from } \\
\text { pigeons }\end{array}$ \\
\hline 5 & M. C. & 24 & F & 16 & 104.4 & 9,000 & 8 & M-P & $\begin{array}{l}\text { pre } \\
25\end{array}$ & $\begin{array}{c}0 \\
1: 32\end{array}$ & Laboratory infection \\
\hline 6 & J.P. & 54 & $\mathbf{M}$ & $14+$ & 107 & 6,000 to 7,900 & & & & & $\begin{array}{l}\text { Source of infection undeter- } \\
\text { mined }\end{array}$ \\
\hline 7 & L. S. & 53 & F & $13+$ & 105.8 & 12,200 to 5,800 & 13 & $\begin{array}{l}\text { S-F } \\
\text { (lung- } \\
\text { spleen) }\end{array}$ & & & Nurse. Contact with Case 6 \\
\hline 8 & N. F. & 35 & F & $13+$ & 105.4 & 8,850 to 27,560 & 13 & $\begin{array}{l}\text { S-F } \\
\text { (lung) }\end{array}$ & & & Nurse. Contact with Case 6 \\
\hline 9 & H. P. & 29 & $\mathbf{M}$ & 14 & 105.2 & 6,300 to 10,500 & 8 & S-F & $\begin{array}{l}\text { pre } \\
21\end{array}$ & $\begin{array}{l}0 \\
1: 16\end{array}$ & Laboratory infection \\
\hline 10 & M. B. & 42 & $\mathbf{F}$ & 15 & 103.6 & 11,000 & 14 & S-F & $\begin{array}{r}8 \\
17\end{array}$ & $\begin{array}{l}1: 16 \\
1: 128\end{array}$ & Laboratory infection \\
\hline 11 & M. M. & 35 & $\mathbf{M}$ & $14+$ & 105 & 6,200 & & & & & $\begin{array}{l}\text { Source of infection undeter } \\
\text { mined }\end{array}$ \\
\hline 12 & M. D. & 53 & $\mathbf{F}$ & $13+$ & 105.8 & 8,700 to 10,400 & 13 & $\begin{array}{c}\text { S-F } \\
\text { (lung) }\end{array}$ & 10 & $1: 8+$ & $\begin{array}{l}\text { Nurse. Contact with Case } \\
11\end{array}$ \\
\hline
\end{tabular}

+denotes fatal case.

* P.O. = Pigeon ornithosis virus; $\mathrm{M}-\mathrm{P}=$ meningopneumonitis virus; $\mathrm{S}-\mathrm{F}=$ pneumonitis virus identical with type strain S-F. Viruses isolated from sputum unless otherwise noted.

3,200 on May 22. X-rays taken on May 14 and May 21 showed an extension of the infiltration in the L.U.L., but no spread to other lobes.

Course: The patient ran a severe febrile course with frequent chills. Temperature ranged from $101^{\circ}$ to $104^{\circ} \mathrm{F}$. from the 9th to the 21st day. Auricular fibrillation continued, but the ventricular rate was controlled by digitalization. Sputum became copious and was at times rusty in character. He became incontinent on May 15 and irrational on May 19. From that time on he refused to take food. A right-sided parotitis complicated his illness between May 18 and May 24. Despite his cardiac status and poor nutritional state, the patient's temperature gradually fell and reached normal on May 28 . Chest findings cleared. He remained irrational and on May 30 became markedly worse and died on May 31, 1942.

Autopsy findings: Postmortem examination was remarkable for the paucity of positive findings. Small amounts of clear fluid were found in both pleural cavities. There was no consolidation in either lung, nor was there evidence of pulmonary embolus. The spleen was enlarged to three times normal size and on section was greyish-red in color, pulpy in character. Microscopic examination of lung section taken from the L.U.L. showed thickening and fibroplastic proliferation in the interstitial tissue, areas of atelectasis, flattening of bronchiolar epithelium, and scattered aggregates of large and small round cells. The serous exudate in the alveoli was entirely devoid of nucleated cells. 
Isolation of virus: The virus of pigeon ornithosis was isolated from sputum obtained on the 10th day of disease, but efforts to recover the same agent from lung and spleen tissue obtained at autopsy were unsuccessful.

Epidemiology: Shortly before the onset of his illness, B. S. had obtained 4 pigeons with the intention of eating them. The birds were not alive at the time of investigation and were presumably eaten. Other members of his family did not become ill. Three pigeons of the flock from which B. S.'s pigeons originated were examined by Dr. Meyer at the Hooper Foundation. From the livers and spleens of 2 birds, the virus of pigeon ornithosis was isolated. Dr. Meyer has very kindly allowed us to use this strain in cross-immunity tests to be described later in this paper. It was further learned that the original owner of this flock, J. C., male, 60, had died on April 19, 1941 as the result of an atypical pneumonia. The exposure to presumably infected birds and the nature of his illness offer suggestive, though by no means conclusive, evidence that he also was infected with the virus of pigeon ornithosis.

Case 2. M. P., male, 38, noted malaise, fever, and cough on May 7, 1942 and was admitted to the hospital about one week later. Chest $x$-ray showed pneumonic infiltration in the right hilar region. For 3 weeks, the patient remained seriously ill, running a high spiking fever. Temperature reached normal on June 11, 1942. Convalescence was slow but uneventful.

Epidemiology: Two weeks prior to the onset of his illness, ' M. P. had visited a relative who owned a parrot, 8 pigeons, and 8 chickens. His visit lasted one-half hour. He did not handle any of the birds. With his wife, he picked and later ate some lettuce planted close to the pen in which the pigeons were kept. All the birds appeared healthy. All pigeons and chickens were bled and failed to show complement-fixing antibodies to psittacosis virus. According to Meyer, however, this does not exclude latent infection. The evidence that M. P. acquired his infection during this visit is suggestive only.

Case 3. A. B., female, 36, became ill on July 3, 1942, complaining of malaise, fever, and cough with bloody sputum. She was admitted to the hospital on July 5 . Physical examination showed an acutely ill patient with an extensive bronchopneumonia. On July 7, marked dyspnea and cyanosis were noted. Dyspnea persisted throughout the serious phase of her illness. Following a week during which the patient's temperature ranged between $102.6^{\circ}$ and $104.3^{\circ} \mathrm{F}$. and her condition appeared critical, gradual improvement occurred. Temperature remained normal after July 22, 1942.

Epidemiology: For a considerable period, A. B. had fed a flock of wild pigeons from the back window of her apartment, the closeness of contact being undetermined. It was impossible to obtain any of the birds for study.

Case 4. R. C., male, 48 , became ill suddenly on March 19,1943 , complaining of generalized aches and pains, sore throat, "terrific" headache, nausea, and vomiting. He was admitted to the hospital on March 23. Temperature was $103.2^{\circ} \mathrm{F}$., pulse 88 , respirations 22 . On physical examination, he appeared acutely ill. Pharynx was ex- tremely red and bronchial breathing was noted over R.M.L. and L.L.L. Severe chills occurred repeatedly. Cough was severe and produced blood-tinged sputum. Abdominal distention was troublesome. Temperature remained between $102^{\circ}$ and $105.6^{\circ} \mathrm{F}$. Respirations rose steadily and exceeded 30 during the second week of illness. X-ray on March 24 showed an infiltrating lesion in the L.L.L. with accentuated bronchovascular markings throughout. On March 31, the pneumonic infiltration had spread and areas of increased density were observed in the R.U.L., R.M.L., and scattered throughout the left lung field. On March 28, the patient became irrational. Pulse rate, which had remained below 110 , rose rapidly. Death occurred on April 2, 1943. Autopsy was not performed.

Isolation of virus: Sputum obtained on March 29, 1943 was inoculated intranasally into 2 cotton rats. Both appeared ill on the second day. One was sacrificed on the 4th day and showed extensive pulmonary infiltration. Impression smears of the lungs contained numerous elementary bodies. Passage in mice showed that the strain had the properties of the pigeon ornithosis virus.

Epidemiology: In December 1942, R. C. acquired 32 pigeons which he kept in a shed behind his house. Two weeks before the onset of his illness, he cleaned the shed for the first time, removing all the dry and dusty droppings. Seven pigeons were obtained and taken to Dr. Meyer for testing. Six of these showed strongly positive complementfixation tests for psittacosis and virus was recovered from 6 birds. None of the 4 other members of the family, who had only casual contact with the pigeons, showed evidence of infection or significant elevation of complement-fixation titer.

Cases not related to contact with birds. These include 3 cases in nurses and 3 laboratory infections. The data on these 6 cases and 2 related cases are summarized in Table I.

Case 5. M. C., female, 24, a laboratory technician, became ill on March 20, 1942 with chills, fever, malaise, cough, and severe headache. The course was milder than in any of the other cases and there was very little clinical or x-ray evidence of pulmonary involvement. M. C. had been using meningopneumonitis virus grown in chick embryos for complement-fixation tests, but had no known contact with birds. A virus indistinguishable from meningopneumonitis and pigeon ornithosis was isolated from sputum by intranasal inoculation of cotton rats and mice.

The strain of virus designated S-F was originally isolated from 2 nurses who presumably became infected while taking care of a patient with an atypical pneumonia. Brief descriptions of these cases were presented in the original report (1). Clinical data, however, were not presented but are of sufficient interest to warrant a brief summary here.

Another patient-to-nurse infection occurred in 1942 and a virus identical with the original S-F strain was again isolated. In addition, there were 2 laboratory infections 
with this strain which differed from the naturally occurring cases only in the fact that they were somewhat less severe.

Case 6. J. P., male, 54, became ill on March 5, 1940 and was admitted to the hospital on March 8. X-ray showed bronchopneumonia at the right base. Blood culture was negative. Fever remained high and no effect was noted following treatment with sulfapyridine. The patient died on March 18, 1940. Autopsy was not performed and no sputum or blood specimens were obtainable.

Case 7 (Figure 2). L. S., female, 53, a general duty nurse on the floor on which J. P. was a patient had numer.

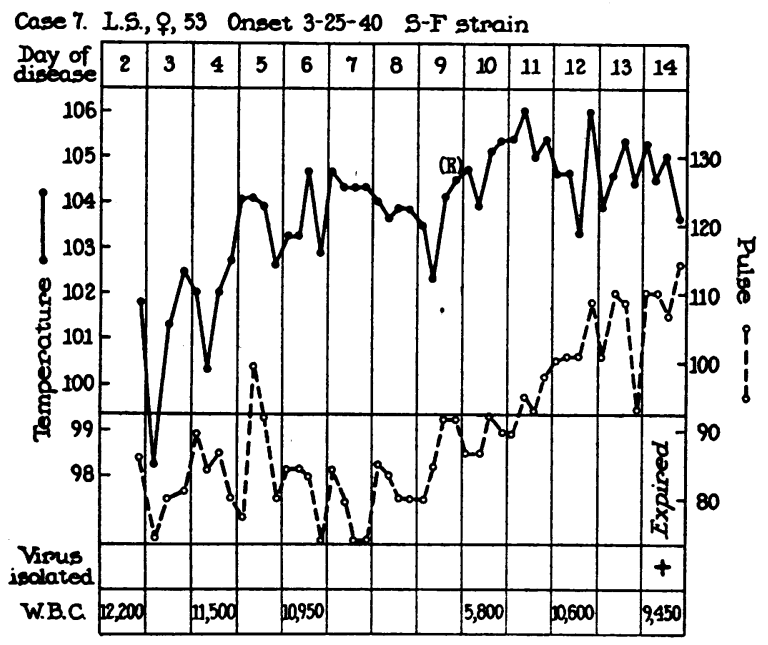

Fig. 2. Case Due to S-F Strain, Not Related to Contact with Birds

ous opportunities for exposure between March 8 and March 12,1940 . She became ill suddenly on March 25 , complaining of severe frontal headache, nausea, dull abdominal pain, and a severe chill which lasted 10 to 15 minutes. On admission to the hospital on March 26, temperature was $101.8^{\circ} \mathrm{F}$., pulse 86 , respirations 24 . Physical examination was entirely negative. White blood count was 12,200 (polymorphonuclear leukocytes 88 per cent). X-ray showed an area of increased density in the upper right lung field which was interpreted as an area of bronchopneumonia. Blood culture was negative. The patient's course was extremely stormy, with temperature for the most part between $103^{\circ}$ and $105.8^{\circ} \mathrm{F}$., pulse 86 to 110 , and respirations, during the second week, consistently over 42. Death occurred on April 7, 1940.

Autopsy showed a lesion involving most of the right upper lobe, the tissue being rather solid, but still slightly crepitant and greyish-red in color. A thin fibrinous exudate covered the pleura. Spleen was large and soft. On microscopic examination, the pulmonary alveoli were found to contain a loose exudate of fibrin with only moderate numbers of cells. In most areas, large mononuclear cells predominated with scattered areas of hemorrhage and very few lymphocytes or polymorphonuclear leukocytes. Many macrophages were loaded with pigment probably derived from hemoglobin. Parts of the involved lobe contained a denser, more cellular exudate with relatively larger numbers of polymorphonuclear leukocytes. The pathology in this case was very similar to that of psittacosis (11) and also to certain other virus pneumonias not caused by psittacosis-like agents. A psittacosis-like virus (strain S-F) was isolated from lung and spleen (1) obtained at autopsy.

Case 8. N. F., female, 35, was a relief nurse who had brief exposures to J. P. between March 8 and March 18, 1940. On March 25, she noted severe headache and anorexia. She was admitted to the hospital on March 27 and died on April 7, 1940. Clinical course and postmortem findings were very similar to Case 7 except that on physical examination, stiffness of the neck and Kernig's sign were observed.

Of 3 special nurses who cared for J. P. from March 12 to March 17, 1940, one, B. M., female, 35, became ill with a pneumonia similar to those described, but recovered after a prolonged illness. Clinical information was not obtained and etiological studies were not done. Complementfixation test with psittacosis antigen was positive in a dilution of $1: 256$ following recovery.

Epidemiology: J. P. died as the result of a pneumonia of undetermined etiology. No history of contact with psittacine birds or with pigeons was obtained. Three of 15 nurses who cared for him acquired similar infections, 2 terminating fatally.

Cases 9 and 10 were laboratory infections which occurred during investigation of the $S-F$ virus.

Case 9. H. P., male, 29, noted weakness on August 10, 1940. On August 11, he became acutely ill with headache, malaise, chill, and fever. He was admitted to the hospital on that day. Temperature was $103.2^{\circ} \mathrm{F}$., pulse 94, respirations 24. Physical examination showed a flushed, feverish patient. Pharynx was moderately inflamed. Chest examination was negative.

Course: Temperature remained high, ranging from $102^{\circ}$ to $105.2^{\circ} \mathrm{F}$. Cough with scanty sputum was noted on August 12. Moist râles were heard at the left base on August 16. On August 19, marked prostration, lethargy, and incontinence were observed. Chest examination showed dullness, tubular breath sounds, and showers of râles at the left base. On August 20,100 cc. of serum from a patient convalescent from a similar illness (the nurse B. M., connected with Cases 6, 7, and 8) was given intramuscularly. Marked improvement was noted the following day. An additional $50 \mathrm{cc}$. of convalescent serum was given on August 22. The patient's temperature fell to normal on August 23, 1940, and remained normal thereafter. Recovery was fairly rapid.

$\mathrm{X}$-ray on August 16 failed to show evidence of pneumonia. On August 20, chest $x$-ray showed a large patch of pneumonia at the left base. On August 23, this area of infiltration had almost entirely cleared.

Case 10. M. B., female, 42, became ill suddenly on August 15, 1940, 4 days after H.P. Her complaints were severe backache, chill, fever, headache, nausea, and vomiting. On August 18, she began to have non-productive 
cough and aching pains in the left chest and shoulder. On August 22, she was admitted to the hospital. Temperature was $101^{\circ} \mathrm{F}$., pulse 120 , respirations 30 . Physical examination showed a moderately ill patient with evidence of bronchopneumonia in the L.L.L.

Course: Following 6 stormy days during which temperature rose to $103.6^{\circ} \mathrm{F}$, the patient's condition gradually improved. Temperature reached normal on August 29, 1940, and remained normal apart from a spike of fever on September 3. Convalescent serum from a patient who had recovered 5 months previously from a similar illness and from a normal donor with high antibody titer for psittacosis was given intramuscularly, in small daily doses, from August 23 to August 25, $160 \mathrm{cc}$. in all. No clear-cut effect was noted. Convalescence was extremely slow and was complicated by severe neuritis and arthritic pains.

$\mathrm{X}$-ray on August 22 showed bronchopneumonia in the L.L.L. Later films showed a migratory type of pneumonia, involving in succession the midportion of the left field, the left base, and the right hilar region. By September 3, these areas had cleared for the most part, but new areas of infiltration were noted at the right base.

Case 11. M. M., male, 35, was admitted to the hospital on January 28,1942 , suffering from an extremely severe diffuse bronchopneumonia of approximately one week's duration. His temperature ranged from $103.8^{\circ}$ to $105^{\circ} \mathrm{F}$. White blood count was 6,200 . Sulfonamide drugs were given without benefit. He failed rapidly and died on February 3, 1942. Autopsy was not performed.

Case 12. M. D., female, 53, a nurse, was in contact with Case 11 from January 28 to February 3, 1942. On February 10, she suddenly became ill with high fever, repeated severe chills, headache, anorexia, nausea, vomiting, and cough. Sputum was very scanty. Her condition rapidly became worse and she was admitted to the hospital on February 17. At that time, temperature was $105^{\circ} \mathrm{F}$., pulse 84 , respirations 24 , blood pressure 160/80. On physical examination, the patient appeared seriously ill, though lying quietly flat in bed with only slight dyspnea. Pharynx was injected. Chest examination showed dullness at the left base and bronchial breath sounds and moist rales over the whole left side. Spleen was not felt.

Laboratory findings: Urine showed a heavy trace of albumin. Sputum, obtained by throat swab, showed no pneumococci, but a heavy growth of hemolytic staphylococcus aureus. $\mathrm{X}$-ray on February 17 showed a moderate amount of fluid in the left costophrenic angle, a diffuse patchy bronchopneumonia of the whole left lung, and a small amount of patchy pneumonia at the right base.

Course: Sulfadiazine was given in doses of 6.0 grams daily and a blood level of $14.0 \mathrm{mgm}$. per cent was obtained without apparent benefit. On February 18, $110 \mathrm{cc}$. of clear yellow fluid were removed from the left pleural cavity. This fluid was sterile on culture. On February 20, the patient suddenly became cyanotic and unconscious with marked generalized rigidity. She remained in coma until her death on February 22, 1942. Autopsy was not performed.

Isolation of virus: One cc. of fluid was obtained by lung puncture on February 22. Culture showed hemolytic staphylococcus aureus. Virus was obtained by mouse passage.

Epidemiology: Although the etiology of the pneumonia in the original case was not determined, the similarity of his illness and the known person-to-person communicability of this agent makes it likely that M. D. contracted her infection as a result of exposure to him. The origin of M. M.'s infection remains uncertain. It was learned that he had lived for 2 years in close proximity to chickens, but no information relative to other avian contact was obtained.

Among 6 naturally occurring infections presumably due to the psittacosis-like strain S-F, 4 occurred in nurses in attendance on the 2 original patients. This points to a high personto-person communicability. Five of the 6 cases terminated fatally, an exceedingly high mortality. The 2 laboratory infections occurred during routine investigation of the virus and reemphasize the danger of work with agents in the psittacosis group, particularly when inoculations are done by the intranasal route.

Clinical diagnosis. All available evidence indicates that it is impossible to distinguish clinically the infections due to the agents described from each other or from psittacosis. The question arises whether it is possible to differentiate clinically between pneumonias due to psittacosis-like viruses and the prevalent type of primary atypical pneumonia which is not caused by these agents. On the basis of the present data, this question must be answered in the negative. Certain points, however, may be of definite assistance. In general, the large majority of primary atypical pneumonias are mild, with a comparatively small proportion moderately severe, and an even smaller proportion extremely severe or fatal. The case fatality among several hundred cases which we have observed has not exceeded one per cent. With the psittacosis-like viruses, on the other hand, the majority of infections have been moderately or extremely severe and the case fatality has been high. Consequently, it is with the severely ill patient that the question of differentiation becomes important.

Among the symptoms which have been, in our experience, more common in the psittacosis-like group, the following deserve mention. Chills occur more frequently, usually near the onset, and may occur repeatedly during the first week. Gastrointestinal symptoms are frequently pres- 
ent. The patient often appears desperately ill even though the area of pulmonary infiltration is not great and respiratory distress is slight. In the correspondingly severe cases in the other group which we have observed, the pulmonary infiltration has involved most of one lung and frequently part of the other, and respiratory distress is extreme. Marked disturbance of cerebral functions is almost the rule. A final point, useful for the most part in retrospect, is the greater duration and height of the fever.

\section{LABORATORY STUDIES}

Ten strains of virus have been isolated from sputum or autopsy specimens obtained from the cases of pneumonia just described. The properties of the strains isolated from Cases 7, 8, 9, and 10 in 1940 have been described in detail in previous publications $(1,22,23)$. These strains were compared with 6 additional strains isolated in 1942-43.

Method of isolation of virus from sputum or autopsy specimens. Sputum or tissue was ground thoroughly in a mortar with alundum and diluted with plain infusion broth $(\mathrm{pH} 7.6)$ or with 10 per cent horse serum broth to make a 10 to 20 per cent suspension. Coarse material was allowed to settle or was centrifuged out at low speed.

Four white mice were inoculated intranasally under ether anesthesia with $0.05 \mathrm{cc}$. of suspension. The mice were kept in strict isolation. At the end of 4 to 7 days, they were sacrificed, the lungs removed with sterile precautions, and examined for areas of consolidation, particularly small round grey foci as described by Eaton, Beck, and Pearson (1). Cotton rats were used in some cases for first passages. Pulmonary findings resembled those in mice. Subsequent passages were carried in mice.

The first passage mouse lungs were ground with alundum and broth to make a 10 per cent suspension and inoculated in amounts of $0.05 \mathrm{cc}$. intranasally, $0.03 \mathrm{cc}$. intracerebrally, and $0.5 \mathrm{cc}$. intraperitoneally into 3 groups of mice. Mice dying from intranasal and intracerebral inoculations were examined for elementary bodies by making impression smears of the lungs and brains and staining by the method of Macchiavello.
Usually, those mice receiving intracerebral inoculations with positive material died in 3 to 5 days and the brain smears showed many elementary bodies. Mice inoculated intranasally did not always die on the second passage, but usually showed marked greyish-red consolidation of the lungs and positive smears.

Psittacosis or pigeon ornithosis is carried at least 21 days or longer in the liver and spleen of mice. On the other hand, it has been 'reported that the S-F strain cannot be recovered after 9 days from the livers and spleens of mice following intraperitoneal inoculation $(1,23)$. This variation was considered significant and all new strains isolated were given this differential test. The second-passage mice inoculated intraperitoneally were held for 21 days. They were then autopsied and examined particularly for enlargement of liver and spleen, hepatic necrosis, peritoneal exudate, fibrin, and ballooned intestines. The liver and spleen were ground in a mortar and a 10 per cent broth suspension was made. This material was inoculated intranasally and intracerebrally into normal mice to determine if the virus was still present in these organs.

Properties of the strains isolated. All strains included in this study formed minute coccoid elementary bodies, demonstrable in impression smears of the brains and lungs of mice, and all were fatal to mice when inoculated by the intranasal and intracerebral routes. Only 2, however, strain B.S. from Case 1 and strain M.C. from Case 5, showed marked virulence for mice by the intraperitoneal route, B.S. killing irregularly and M.C. killing in dilutions of $10^{-3}$ and $10^{-4}$. Mice inoculated intraperitoneally with each strain were tested at the end of 21 days for the carrier state. Four strains (S-F, H.P., M.B., and M.D.) from Cases 8, 9, 10, and 12, respectively, produced no carrier state at the end of 21 days. However, livers and spleens from mice receiving the strains B.S., M.P., A.B., R.C., or M.C. (Cases 1, 2, 3, 4, and 5) killed mice, subinoculated intracerebrally, in 3 to 5 days and caused lung consolidation with typical elementary bodies at the end of 7 days, in mice subinoculated by the intranasal route.

There was apparently some correlation between the epidemiological history and the properties of the virus in mice. Eliminating the 
3 laboratory infections, 3 out of 7 patients gave definite information of exposure to pigeons. In the case of M. P., a history of fleeting exposure to pigeons with negative serology was obtained. The virus isolated from known or presumed pigeon-contact cases (B. S., M. P., A. B., and R. C.) differed in mouse pathogenicity from the strains obtained from 3 secondary cases in nurses L. S., M. F., and M. D.

Cross-immunity tests. The differences between the strains, as demonstrated by pathogenicity after intraperitoneal inoculation of mice, were confirmed by cross-immunity tests. Mice were immunized by 1 or 2 intraperitoneal inoculations with active virus and tested 3 weeks later by the intracerebral route using 10 to 100 minimal lethal doses (MLD) of strain S-F and 10 MLDs of pigeon ornithosis virus. The latter strain was isolated by Dr. Meyer from pigeons connected with Case 1. A summary of the results is presented in Table II. All members of the group

TABLE II

Intracerebral cross-immunity tests with pigeon ornithosis virus and $S-F$ strain against 8 strains from cases of preumonitis

\begin{tabular}{|c|c|c|c|c|c|c|c|c|}
\hline \multirow{3}{*}{ Case } & \multirow{3}{*}{$\begin{array}{c}\text { Strain } \\
\text { of } \\
\text { virus } \\
\text { for } \\
\text { immu- } \\
\text { niza- } \\
\text { tion }\end{array}$} & \multirow{3}{*}{ Route } & \multicolumn{6}{|c|}{ Results after test with strain: } \\
\hline & & & \multicolumn{3}{|c|}{ S-F } & \multicolumn{3}{|c|}{ Pigeon ornithosis } \\
\hline & & & MLD & D & $\mathbf{P}$ & MLD & D & $\mathbf{P}$ \\
\hline $\begin{array}{l}1 \\
2 \\
3 \\
5 \\
7 \\
9 \\
10 \\
10 \\
12 \\
\text { Controls } 8\end{array}$ & $\begin{array}{l}\text { B. S. } \\
\text { A. B. } \\
\text { M. P. } \\
\text { M. C. } \\
\text { S-F. } \\
\text { H. P. } \\
\text { M. B. } \\
\text { M. D. } \\
\text { nil }\end{array}$ & $\begin{array}{l}1 x \text { IP } \\
1 x \text { IP } \\
1 x \text { IP } \\
1 x \text { IP } \\
1 x \text { IP } \\
1 x \text { IP } \\
2 x \text { IP } \\
2 x \text { IP } \\
1 x \text { IP } \\
-\end{array}$ & $\begin{array}{l}10-100 \\
10-100 \\
10-100 \\
10-100 \\
10-100 \\
10-100 \\
10-100 \\
10-100 \\
10-100 \\
10-100\end{array}$ & $\mid$\begin{tabular}{l|}
$0 / 6$ \\
$0 / 5$ \\
$0 / 12$ \\
$1 / 13$ \\
$0 / 10$ \\
$0 / 21$ \\
$0 / 7$ \\
$0 / 7$ \\
$0 / 12$ \\
$22 / 27$
\end{tabular} & $\begin{array}{l}0 / 6 \\
0 / 5 \\
0 / 12 \\
0 / 12 \\
0 / 10 \\
0 / 21 \\
0 / 7 \\
0 / 7 \\
0 / 12 \\
1 / 5\end{array}$ & $\begin{array}{c}10 \\
10 \\
10 \\
10 \\
10 \\
10 \\
100^{*} \\
100^{*} \\
10 \\
10\end{array}$ & \begin{tabular}{|c|}
$0 / 13$ \\
$0 / 6$ \\
$2 / 11$ \\
$1 / 14$ \\
$6 / 10$ \\
$13 / 14$ \\
$6 / 7$ \\
$5 / 7$ \\
$14 / 15$ \\
$23 / 23$
\end{tabular} & $\begin{array}{l}0 / 13 \\
0 / 6 \\
0 / 9 \\
0 / 13 \\
4 / 4 \\
1 / 1 \\
1 / 1 \\
2 / 2 \\
0 / 1 \\
0 / 0\end{array}$ \\
\hline
\end{tabular}

1x IP, $2 x$ IP $=1$ or 2 immunizing intraperitoneal inoculations.

$\mathrm{D}=$ deaths; numerator number of deaths, denominator number of mice tested.

$\mathbf{P}=$ residual paralysis/mice surviving.

* = tested with meningopneumonitis virus.

protected completely against the S-F type strain, but strains S-F, H.P., M.B., and M.D. gave no immunity against pigeon ornithosis, the surviving mice in most instances being paralyzed. The remaining strains tested-B.S., M.P., A.B., and M.C.-produced solid immunity to pigeon ornithosis.

The results of cross-immunity tests place the S-F, H.P., M.B., and M.D. strains in the same antigenic group, and distinguish them from the pigeon ornithosis strains B.S., A.B., and B.C. Strains of the S-F type may be distinguished from psittacosis by similar methods (23). Strain M.C. is similar in pathogenicity to pigeon ornithosis and cross immunity is complete to this virus. It would appear to be necessary to correlate pathogenicity in animals, cross-immunity tests, and epidemiological history before a strain of psittacosis-like virus can be finally identified.

\section{DISCUSSION}

In the course of the investigations of the group of diseases which is at present called primary atypical pneumonia, it has become clear that a small proportion of these infections is caused by psittacosis-like viruses. This group includes a number of viruses, 3 of which, namely psittacosis, the pigeon ornithosis virus, and the S-F strain, have to date been isolated from naturally occurring human infections. Evidence that these agents may be differentiated by laboratory procedures has been presented (21, 22, 23). Psittacosis has long been known to cause this type of pneumonia and its clinical picture and source of infection have been intensively studied. Recognition of the fact that a related virus, carried by pigeons (10), may cause illness in humans is a recent development and is due almost exclusively to the work of K. F. Meyer and B. Eddie. Their reports $(2,4,8)$ emphasize the widespread distribution of this virus in pigeons and also point out that it may be found in doves and chickens (3). Other reports indicate that this agent is present on other continents $(16,17)$.

The source of viruses represented by the type strain S-F, whether avian or non-avian, is still undetermined. From the available data, it appears that strains of this type have a relatively higher virulence for human beings and a lower virulence for birds $(1,23)$ than the pigeon ornithosis virus. Person-to-person communicability, such as from patient to nurse in Cases 7, 8 , and 12 , is of importance because the secondary infections are frequently severe or fatal. Strains of the S-F type may represent viruses which have become adapted to human beings as a result of one or more direct human transmissions, losing 
in the process some of the pathogenicity for mice and birds and part of the antigenic composition of classical psittacosis strains. As a provisional term, pseudo-psittacosis is suggested to designate those atypical pneumonias caused by strains like the S-F type which are of undetermined origin and which differ significantly in properties from the viruses of psittacosis and ornithosis. When the origin of the S-F type strains is definitely determined, a name based on the source could replace this group nomenclature.

Other psittacosis-like viruses have been isolated from animals. Although the meningopneumonitis virus was isolated by Francis and Magill from ferrets (9), the close similarity of this agent to ornithosis virus suggests an original avian source. Recently, viruses differing in several properties from those described above have been isolated from mice (18) and cats (19). To date, none of these animal viruses has been recovered from human cases, a possible exception being the laboratory infection with menigopneumonitis virus (Case 5).

The frequency of infections due to the psittacosis-like viruses in this area is not great when compared with that of the primary atypical pneumonias as a whole. During the period of this study, over 250 specimens of sputum or lung from patients with primary atypical pneumonia have been inoculated intranasally into mice, cotton rats, or both. Either animal is very susceptible by this route. Psittacosis-like viruses have been recovered only 10 times. Data acquired by complement-fixation tests suggest that four or five other cases of psittacosis-like infection from which no virus was isolated also occurred. Small antibody increases have been observed in various acute respiratory diseases for which the causative agent could not be identified. It remains to be determined whether these are due to a minor antigenic component in other etiologic agents, to anamnestic reactions, or to heterogenetic immunity. In several cases, an unrelated agent was apparently transmitted to cotton rats (25).

Certain previous reports $(6,14,20)$ have put the incidence of psittacosis-like infection much higher than in our experience. The explanation for this difference probably lies in the selection of material. When the incidence of primary atypical pneumonias has been low, psittacosislike viruses may be responsible for a relatively large proportion of the cases. When primary atypical pneumonia has occurred in epidemic form, as reported by Dingle and his co-workers (15), the proportion of cases due to psittacosislike infection has been low.

Although the number of infections due to the psittacosis-like viruses is not large, these cases are important because of their severity and high mortality. Mild infections with the psittacosislike viruses undoubtedly occur, but they have been uncommon in the group which we have studied. On the other hand, primary atypical pneumonias caused by other agents (25) are usually not severe. The number of deaths caused by psittacosis-like agents approaches in frequency the number from all other forms of primary atypical pneumonia.

In the majority of recent reports, the diagnosis of psittacosis-like infection has been based on the complement-fixation test. This test as a diagnostic procedure for psittacosis-like infection has many limitations. Because of the group-specific character of the reaction (24) it gives little information as to the type of virus or source of infection. Other diseases, especially lymphogranuloma venereum (21), may produce high antibody titers with psittacosis antigen. Demonstration of complement-fixing antibodies in a single specimen of serum from a case of atypical pneumonia does not by itself justify a diagnosis of psittacosis or a related disease, although the absence of antibodies during convalescence may exclude these diseases. It is possible that, because of the widespread distribution of psittacosis-like viruses in birds and animals, certain normal human beings may have developed antibodies as a result of contact with these agents. It must be remembered that pneumonia of any kind may occur in a person with pre-existing psittacosis antibodies. Even the demonstration of virus or antibodies in birds associated with the case may be coincidental. Isolation of virus from the patient and demonstration, whenever possible, of a definite antibody response associated with the illness constitute, in our opinion, the only satisfactory positive evidence of specific infection. 


\section{SUMMARY}

1. Clinical and epidemiological data have been presented on 10 cases of severe or fatal atypical pneumonia from which psittacosis-like viruses were isolated. The pigeon ornithosis virus was obtained from 4 cases, a different but related virus (S-F strain) from 5 cases, and the meningopneumonitis virus from one.

2. Laboratory data have been presented which show that the S-F strain can be differentiated from the pigeon ornithosis virus. All cases from which ornithosis strains were isolated gave histories of pigeon contact. No case of infection with the S-F strain gave a similar history, but 3 of these cases were in nurses who were exposed to patients with similar illness.

3. The place of the psittacosis-like infections in the larger group of primary atypical pneumonias has been discussed.

4. The usefulness and limitations of the complement-fixation test in the diagnosis of infections due to psittacosis-like viruses have been reviewed.

We are indebted to the following physicians for calling these patients to our attention and for their assistance in obtaining specimens for laboratory study: A. F. Bloomfield, Leroy Briggs, Wm. G. Donald, Stanford Farnsworth, Ben Kondo, A. M. Moody, James Rinehart, John Sampson, Norman Sweet, and Phillip R. Van Horn.

\section{BIBLIOGRAPHY}

1. Eaton, M. D., Beck, M. D., and Pearson, H. E., A virus from cases of atypical pneumonia: relation to the virus of meningopneumonitis and psittacosis. J. Exper. Med., 1941, 73, 641.

2. Meyer, K. F., Phagocytosis and immunity in psittacosis. Schweiz. med. Wchnschr., 1941, 71, 436.

3. Meyer, K. F., and Eddie, B., Spontaneous ornithosis (psittacosis) in chickens the cause of a human infection. Proc. Soc. Exper. Biol. and Med., 1942, 49, 522.

4. Meyer, K. F., Eddie, B., and Yanamura, H. Y., Ornithosis (psittacosis) in pigeons and its relation to human pneumonitis. Proc. Soc. Exper. Biol. and Med., 1942, 49, 609.

5. Stickney, J. M., and Heilman, F. R., Isolation of virus in atypical pneumonia. Proc. Staff Meet., Mayo Clin., 1942, 17, 369.

6. Favour, C. B., Ornithosis (psittacosis); report of 3 cases, and historical, clinical, and laboratory comparison with human atypical (virus) pneumonia. Am. J. M. Sc., 1943, 205, 162.
7. Alicandri, H., Psittacosis. J. A. M. A., 1942, 118, 1214.

8. Meyer, K. F., Ecology of psittacosis and ornithosis (De Lamar Lecture). Medicine, 1942, 21, 175.

9. Francis, T., Jr., and Magill, T. P., An unidentified virus producing acute meningitis and pneumonitis in experimental animals. J. Exper. Med., 1938, 68, 147.

10. Pinkerton, H., and Swank, R. L., Recovery of virus morphologically identical with psittacosis from thiamin-deficient pigeons. Proc. Soc. Exper. Biol. and Med., 1940, 45, 704.

11. Sturdee, E. L., and Scott, W. McD., A disease of parrots communicable to man (psittacosis). Great Britain Rep. Pub. Health and Med. Subj., Ministry of Health, No. 61, His Majesty's Stationery Office, London, 1930.

12. Badger, L. F., Psittacosis outbreak in department store in Pittsburgh. Pub. Health Rep., 1934, 49, 583.

13. Hoge, V. M., Psittacosis in United States; incidence, scientific aspects, and administrative control measures. Pub. Health Rep., 1934, 49, 451.

14. Smadel, J. E., Atypical pneumonia and psittacosis. J. Clin. Invest. 1943, $22,57$.

15. Dingle, J. H., et al., Primary atypical pneumonia, etiology unknown. War Med., 1943, 3, 223.

16. Coles, J. D. W. A., Psittacosis in domestic pigeons. Onderstepoort J. Vet. Science, 15, 141, 1940.

17. Andrewes, C. H., and Mills, K. C., Psittacosis (ornithosis) virus in English pigeons. Lancet, 1943, 1, 292.

18. Nigg, C., Unidentified virus which produces pneumonia and systemic infection in mice. Science, 1942, 95, 49.

19. Baker, J. A., Virus obtained from pneumonia of cats and its possible relation to cause of atypical pneumonia in man. Science, 1942, 96, 475.

20. Reimann, H. A., Havens, W. P., and Price, A. H., Etiology of atypical ("virus") pneumonias, with brief résumé of recent discoveries. Arch. Int. Med., 1942, 70, 513.

21. Eaton, M. D., Martin, W. P., and Beck, M. D., Antigenic relationship of viruses of meningopneumonitis and lymphogranuloma venereum. J. Exper. Med., 1942, 75, 21.

22. Beck, M. D., and Eaton, M. D., Identification of 2 strains of virus isolated from cases of atypical pneumonia. J. Infect. Dis., 1942, 71, 97.

23. Beck, M. D., Eaton, M. D., and O'Donnell, R., Further laboratory studies on the classification of psittacosis-like agents. J. Exper. Med., 1944, 79, 65.

24. Eaton, M. D., and Corey, M., Complement-fixation in human pneumonitis with group-reactive virus antigens. Proc. Soc. Exper. Biol. and Med., 1942, $51,165$.

25. Eaton, M. D., Meiklejohn, G., Van Herick, W., and Talbot, J. C., An infectious agent from cases of atypical pneumonia apparently transmissible to cotton rats. Science, 1942, 96, 518. 